\title{
Inconvenient truth or public health threat?
}

For Tim Noakes, the University of Cape Town's 'great centenary debate' on what constitutes a healthy diet was a 'kangaroo court', deliberately set up to discredit the 'inconvenient and threatening truths' behind his relatively recent and muchtouted high-fat, no sugar, no carbohydrates eating regimen.

For his scientific peers and opponents, however (and possibly most of the audience that gathered at UCT's Learning Centre lecture theatre, the 6 December debate being streamed live on the internet and to the nearby Sports Science Centre), he's a threat to the lay public's health and a self-confessed 'cholesterol denialist'. The scene was set for an epic academic debate between the charismatic Noakes and fellow UCT graduate and fellow A-rated scientist, Jacques Rossouw, the Washington-based epidemiologist on heart disease prevention and former director of the local Medical Research Council's Institute for Nutritional Diseases.

Ultimately, however, it proved somewhat disappointing, although highly educational, with no clear 'winner', Noakes dramatically declining a 10-minute rebuttal of Rossouw's wideranging presentation. As the country's pre-eminent sports scientist explained to Izindaba afterwards, 'it was a kangaroo court ... that's why I withdrew. I knew they had the big guns there waiting to fire so I limited myself in getting into the debate. I have an international reputation to protect. The debate jumped on the bandwagon of free intellectual debate as part of UCT's centenary celebrations, but it was actually a kangaroo court ... I knew it had one goal - to expose me and shut me up. There had been that demeaning and unprofessional letter to the Cape Times from my colleagues at Groote Schuur [Hospital], so I knew there was a body of opinion out there looking for my blood.' He said he was 'astonished' by what he regarded as 'probably the rudest audience I've addressed in 40 years, adding, 'whenever I was criticised, they clapped. That's when I said, OK, I'm cutting my losses and not saying anything more. I can read an audience. The moment I said something, it didn't matter whether I was right or wrong, I could see the hostility was rising. I decided the audience was not mature enough, so I'm out of here.'

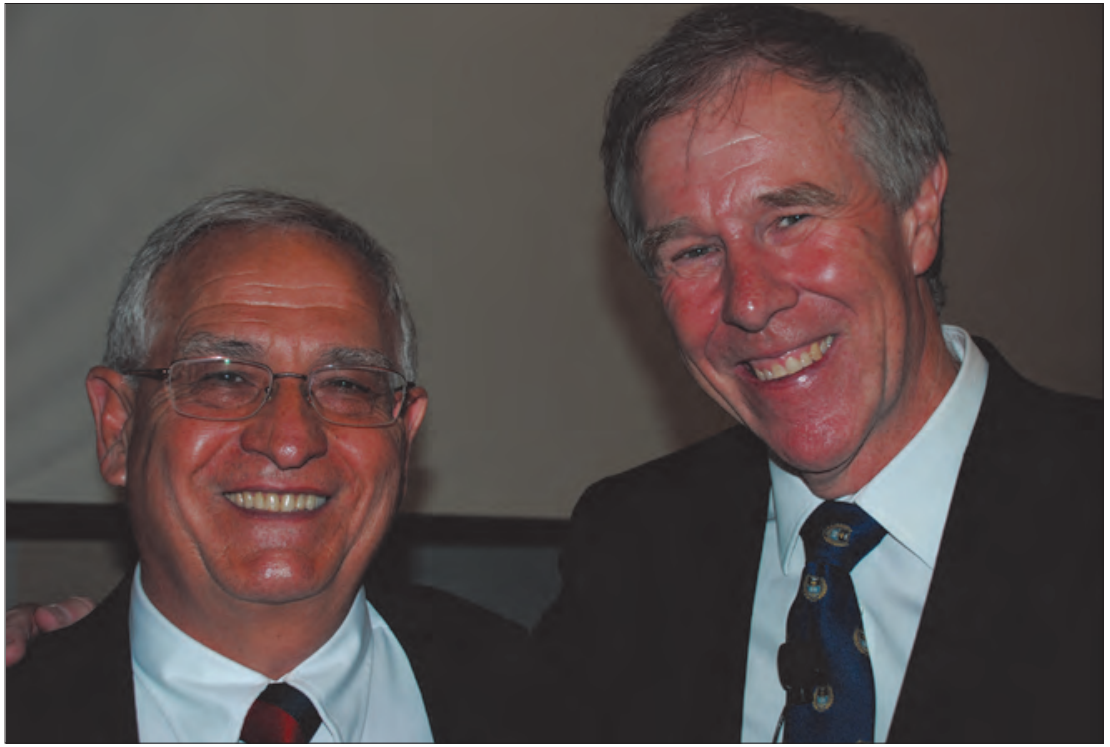

Professors Jaques Rossouw and Tim Noakes. Picture: Chris Bateman.

\section{Statin industry under threat - Noakes}

Noakes suspected Rossouw was flown out to Cape Town by the Heart Foundation 'and other bodies' to silence him because he'd been asking inconvenient questions. He believes the entire statin industry feels threatened by the possibility that his radical departure from conventional scientific wisdom might hold water. Both his assertions were vigorously denied by the debate convenors and Rossouw.

Debate convenor and UCT-based Associate Director of the multi-campus collaboration, the Chronic Diseases Initiative in Africa, Krisela Steyn, said she bumped into her former colleague Rossouw during an academic visit to Washington

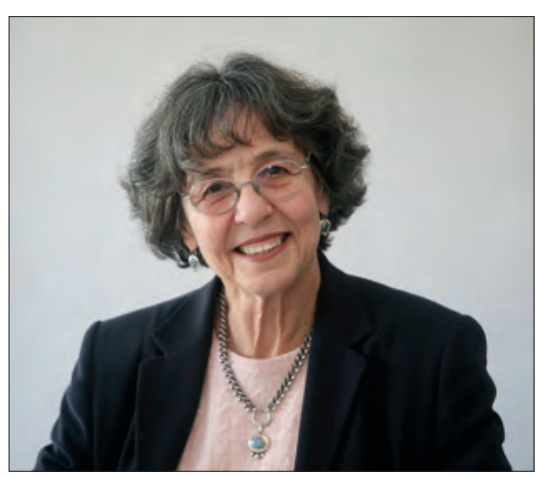

Professor Krisela Steyn, Associate Director of the multi-campus collaboration, the Chronic Diseases Initiative in Africa. last year. Conversation turned to Noakes' nutritional theory. 'He expressed alarm and mentioned that he was coming out to visit family in Cape Town in December. I simply asked whether he was prepared to take part in a UCT debate on the issue - and he agreed.' She said the highly informed debate audience on the night applauded Noakes' antagonists (Noakes presented first) because what he was saying was 'inappropriate'. Fresh from lectures on diet where he had audiences 'spell-bound' at the Mandela Metro University in Port Elizabeth and Rhodes University in Grahamstown, Noakes was under no illusion that Cape Town would be different. He told Izindaba he spent two months preparing his presentation, topped off by a run just before delivery to settle any nerves. 'I'm not saying everybody agreed with me [in the two lectures preceding the UCT debate] but they at least accepted I had a point. One person later tweeted, "I'm going to destroy Noakes". It's fine if this [UCT] audience really are my peers. What have they done in science? What evidence is there that they are open to new ideas? What evidence is there that they've put out anything new and creative, and what evidence is there that they've been right? I've been right in everything that I've put out, with at least four or five major controversies - and I've been right on every one, he simmered two days after the debate. 


\section{Obesity a marker of high carbo diet - Noakes}

This is how Noakes summed up his position to Izindaba just minutes before delivering his UCT presentation, 'Not everyone is able to metabolise carbohydrates safely and there is a (large) population out there that has carbohydrate resistance. I believe it's genetic and gets worse with age. It's nothing to do with just getting fat. Obesity is purely a marker of people eating a high carbohydrate diet with carbohydrate intolerance. No one ever questions whether you're carbohydrate intolerant or not. That's the issue. If you're carbohydrate intolerant you must limit carbs dramatically' Noakes, a pre-diabetic who lost his father to diabetes and has a diabetic child, developed his eating philosophy and lost $17 \mathrm{~kg}$ after researching the history of a low carbohydrate diet for weight loss; from the 1861 Harvey/Banting diet adopted by all major European and North American medical schools for nearly a century, to the Robert Atkins 1974 diet, through to what he describes as the 'momentous' books by Gary Taubes, Good Calories, Bad Calories and Why We Get Fat and What To Do About It.

Rossouw says he's willing to accept that a proportion of people were carbohydrate intolerant before they became diabetic, but believes obesity causes carbohydrate intolerance, not the other way round. The biggest divergence is that Rossouw says he can show that the proportion of truly carbohydrate-intolerant people runs to about six per cent. Noakes claims it's at least ten times this.

\section{As the country's pre-eminent sports scientist explained to} Izindaba afterwards, 'it was a kangaroo court ... that's why I withdrew. I knew they had the big guns there waiting to fire so I limited myself in getting into the debate.'

\section{Noakes out of his depth - Rossouw}

Rossouw: 'It's a small minority. I think Tim got diabetes because he was obese. God forbid one these days that he may have to take medicines made by the evil pharmas - he's a good scientist in his field, but he's way outside of his field and comfort zone here. He doesn't understand the science and the whole concept. He's cherry picked and misinterpreted and is going down a very dangerous path. Applying dietetic measures, he's doing harm and flouting the Hippocratic oath', he warns. Noakes maintains that diabetics do not have higher cholesterol levels than other people, that half of all heart attacks occur in people with normal cholesterol, that glucose is the single most important predictor of risk and that a high-fat diet reverses (almost) all coronary risk factors. He says his diet outperforms studies on 30 other diets and equals studies on another 10. Both agree on the danger of fast foods and sugar (Noakes says sugar should either be banned, highly taxed or restricted), but differ slightly on refined carbohydrates (Noakes' definition of refined being anything with a glycaemic index above 40, which excludes most carbohydrates except leafy vegetables). Rossouw adheres to the common scientific wisdom that bread, pasta, rice and bananas are not refined and therefore fine in moderation. Noakes however believes these are the 'base of the pyramid', producing a large glycaemic load which in time causes problems and wears out the pancreas, producing diabetes and obesity.

He labels Rossouw and his ilk 'the statinators' and himself a cholesterol sceptic 'They want you to be on statins in utero. Their goal is to get the mother on statins. That's their goal ... their only focus is to increase the sales - only when paediatrics are on statins will they be happy. That's the way the industry works.

\section{We're natural carnivores, says Noakes}

His view is that humans evolved to hunt for fat and that there is a craving easily satisfied with a little bit of fat. 'But as soon as you replace this with refined carbos, you get these cravings every three hours (conditioned by food processing to search for refined carbos, especially those with sugar). In today's society this conditioning begins the moment a child comes off the breast and is exposed to high-carbohydrate products. That's why our kids have outrageous behaviour. Whenever you put them on a high-fat diet, their behaviour improves. The reason why we get more obese every generation is the mother eats this high-glucose diet (exposing the infant in utero) and soon after birth the infant begins eating "Puritytype" products full of sugar, adds Noakes. He believes human health began slipping about 12000 years ago with the introduction of agriculture, but dipped radically over the past 35 years after the introduction of the 1977 United States Department of Agriculture Dietary Guidelines, based on an unproven 1953 idea proposed by Ancel Keys $(\mathrm{PhD})$ that dietary fat, especially of animal origin, is dangerous as it increases the blood cholesterol concentration which then 'clogs' major arteries causing especially heart disease and stroke. Noakes believes this to be the greatest single error in modern medicine.

'You'd expect better of Tim. He has a good reputation, so this is extremely dangerous. He's been afforded the (public) space to propound these ideas without scientific validity.'

\section{Noakes' theory 'a public danger' - Steyn}

Steyn says the consequence of Noakes highly publicised theory (he recanted on his high carbohydrate diet so popularised in his book The Lore of Running) is that some people were now even saying that by taking statins your risk of heart disease increased. 'It's dangerous for a certain part of the population at high risk for kidney failure, with high cholesterol or ischaemic heart disease. Damage is being done here. He's radically oversimplified things.' She said it was 'sad' when a good scientist wandered off his area of expertise. 'He's lost the plot a little - he's not basing all his public statements on the best available data. Yes, he's right to question any scientific statement of any type, but please bring the good data.' Steyn said she hoped the charismatic Noakes, whose bona fides she does not question, had a good diabetologist looking after him.

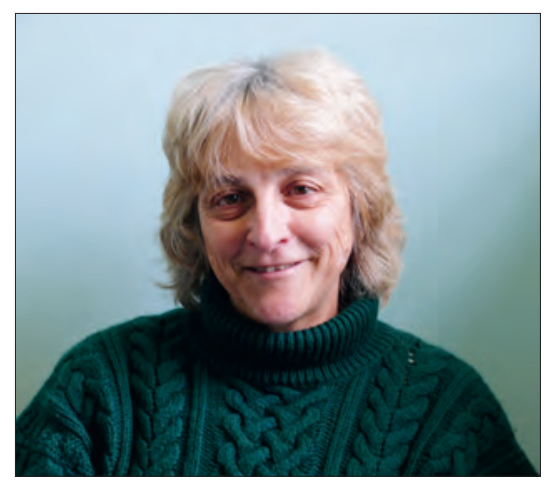

Dinky Levitt, Professor of Endocrinology and Diabetic Medicine at UCT and Director of the Chronic Diseases Initiative in Africa.

'He's entitled to punt something he totally believes in. But what's scary is that he's damaging patients and the population by insisting on this diet for life, regardless of the cost. My overwhelming emotion is sadness that a person of his stature 
has made this mistake.' She cited Linus Pauling, the Nobel Prize winner for chemistry, 'going on a tirade about vitamin C curing the common cold', when it was shown that at best it might reduce the duration of the common cold. 'Then we had Mbeki. The question is how does one get there? If you don't deal with the academic data, a person with public standing can do a tremendous amount of harm.' She said the worst time to 'go to the public with health guidelines' was when academics were still debating the truth for a position. 'You go to the public when you have irrefutable evidence that this is the right thing to do.'

\section{Noakes' theory had the potential to divert people from diets and treatments that were known to do good. 'Were I still a faculty member I'd be very concerned about this member undoing a lot of good work done in heart disease prevention,' said Rossouw.}

Dinky Levitt, Professor of Endocrinology and Diabetic Medicine at UCT and Director of the Chronic Diseases Initiative in Africa, agreed wholeheartedly, describing Noakes as 'irresponsible'. She said the debate had been 'too all encompassing', with too many areas to cover in too little time. 'I think Rossouw showed him up based on science and Tim's rather superficial understanding of epidemiology. It highlighted his lack of appreciation of the complexities of fat metabolism. You'd expect better of Tim. He has a good reputation, so this is extremely dangerous. He's been afforded the (public) space to propound these ideas without scientific validity, she added.

\section{Noakes' diet 'a temporary aberration' - Rossouw}

Rossouw told Izindaba that Noakes would 'find out that the whole (scientific) world out there is a kangaroo court. Except for a very few close followers, the scientific evidence is clear and he's flying against it.' He said the debate on lowering cholesterol with statins (in absolute risk terms by around $2-3 \%$ in a population with a $10 \%$ rate of heart disease) had been 'dead for 20 years'. There was now 'absolute proof' that cholesterol was causal in heart disease. 'Most of the people he cites are zombies from that era and they've been left behind by science. The more Krisela told me about this, the more concerned I became. Noakes' theory had the potential to divert people from diets and treatments that were known to do good. Were I still a faculty member I'd be very concerned about this member undoing a lot of good work done in heart disease prevention. If Noakes came up against anyone in this field he would get the same reception he got at his "faculty meeting" [the centenary debate]. His perception is he was set up to be discredited. But he's in the scientific world and his theories have no standing. Any diet that is calorie and energy restricted will reduce weight. They all work ... for some people the approach he advocates may work better. I have no problem with that, but when you generalise and say everyone should be on the diet permanently, eat your fats and no carbs, that's not right, especially when there are no long-term data on that, while there are data on the conventional diet. Why mess with success? I think five years from now we'll be able to stand back and say where we are ... and the public will have stopped paying attention. I regard this as a temporary aberration. Advocating it for wider health promotion will not stand the test of time.'

According to Steyn and Levitt, the Cochrane Collaboration at the Medical Research Council is due to release a formal review of all existing data on the subject by the end of February 2013. Even that is unlikely to end a debate that has 'long distance' written all over it.

The debate was run according to the Oxford Academic Procedure, and had Noakes proposing that cholesterol is not an important risk factor for heart diseases and that current dietary recommendations do more harm than good. Rossouw used his data to argue that cholesterol is an important risk factor for heart disease and that current dietary recommendations do more good than harm.

\section{Chris Bateman}

chrisb@hmpg.co.za

S Afr Med J 2013;103(2):69-71.

DOI:10.7196/SAMJ.6663 